\title{
SOCIO-POLITICAL TURBULENCE OF THE OTTOMAN EMPIRE: RECONSIDERING SUFI AND KADIZADELI HOSTILITY IN 17 ${ }^{\text {TH }}$ CENTURY
}

\author{
Ahya Ulumiddin \\ State Islamic Institute of Palangkaraya \\ Email: ahyaulumiddin@gmail.com
}

\begin{abstract}
The fierce hostility that happened between the Kadizadelis and the Sufis during the $17^{\text {th }}$ century of the Ottoman Empire is not the new issue in Islamic civilization discourses. During this period, the Empire suffered from massive decadences in almost all sectors. Kadizadelis believed that such phenomenon did not come out of the void. They insisted that the crux of the problem was primarily laid in the heresies and religious innovations (bid'ab) that were promoted largely by the Sufis. Embarking from this suspicion and anxiety, they initiated propagandas in which they aimed to bring back people to re-embracement of the primordial teachings of Islam. Nevertheless, many historians and scholars have doubted Kadizadelis attempts. They suspected that there were other non-religious motives that stirred their revival agendas. This paper presents an analysis that aims to challenge the commonly believed notion in which the Sufis and the Kadizadelis were totally adversarial.
\end{abstract}

Key words: The Ottoman, Sufis, Kadizadelis, innovation, heresy

DOI: http:/ / dx.doi.org/10.20414/ ujis.v20i2.807 


\section{Introduction}

THE OTTOMAN is among the greatest empire ever established within the historical sequence of human civilization. It conquered a vast region of the world's land and dominated a large territory of the seas. Nevertheless, by the $17^{\text {th }}$ century, the Ottoman was already on the verge of collapse. Disorder governmental administration, state-economy inflation, morality decline, and religious deviation, altogether scraped the body of the empire, leaving a rotten structure waiting for falling. ${ }^{1}$

Scholars propose many theories to the decline of the Ottoman. Among the most importance, if not the most unfair and controversial, of all is the uncontrollable mushrooming of religious innovation (bid'ab) that was allegedly motivated by Sufis. Sufi adherents did not attach themselves to the ideal practices of Shariah, thus in most cases they were closer to the permissiveness (ibahiyyah) rather than the standard model of Islamic doctrine. They did not erect the obligation of praying, ignored zakah, and rejected fasting in month of Ramadàn. More extremely, some even consciously declared the truth of religious pluralism, as it was and even now still is, appeared in the mystical doctrine of Bektashi order. Such heresies, according to some scholars, mostly were spread through facilities owned by the Sufi such as lodge (tekke) and coffeehouse. Therefore, in 1633, Sultan Murad IV, with the support of 'Ulama', eventually decreed the banning and the extermination of coffeehouse from the Ottoman soil. ${ }^{2}$

Under the shadow of the Ottoman, Sufis were blessed with luxuriant benefits. Politically, Sufis' influence has penetrated the throne of the Sultan. Some of them were even appointed to be the private tutors for the crown prince as well as for many elites

${ }^{1}$ Richard C Martin, Encyclopedia of Islam and Muslim World (USA: Macmillan and Thomson Learning, 2004), 215-6.

2Rudi Matthee, "Exotic Substance: The Introduction and Global Spread of Tobacco, Coffee, Cocoa, Tea, and Distilled Liquor, Sixteenth to Eighteenth Centuries," in Drugs and Narcotics in History, ed. Roy Porter (Cambridge: Cambridge University Press, 1995), 35. 
within the palace. ${ }^{3}$ In economy, Sufis' businesses such as coffee and tobacco were proved to be highly profitable. The demands for both coffee and tobacco were always growing. It was marked by the widespread establishment of coffeehouses, taverns, gardens, and other amusement sites in all over Ottoman land. Sufis also had a very strong control over educational institution and social life. In short, Sufis' domination over the Ottoman was undoubtedly formidable and pivotal. Nevertheless, the popularity of Sufism seemed to beget other impacts. By the time people's enthusiasm toward the way of Sufi had significantly increased, many socio-political problems emerged, and the most importance of all, which was believed by many revivalists as the main factor of the Ottoman decline, was the issue of morality crisis. Many scholars have studied this issue. For example, Elsye Semerdijan in her investigation over naked anxiety in $17^{\text {th }}$ century Aleppo, signified the moral transgression within the bathhouse by Arab women. Quoting Simeon Lehatsi, she stated,

"Arab women are loose and shameless. They are not ashamed of one another and walked naked and disgracefully. They go to the bath naked and without cover. The bath attendants lay them down and wash private part of men and women." 4

Similarly, Jamse Grehan, who studied the smoking custom of the Ottoman people, mentioned the negative impacts of both coffeehouse and tobacco.

"In sixteenth century Istanbul, they lamented, the mosques now stood empty, as worshippers - including many members of the religious establishment-whiled away their hours in the inviting precincts of the coffeehouse." 5

The impact of such issue then became more sensitive when Sufis began promoting openly anti-Shar'-'ah customs and rituals

'Halil İnalcik, Tärikh al-Dawlah al-Uthmāniyyah min al-Nushū' ilā al-Inḅidār, trans. Mụ̣ammad M. al-Arna'ūṭ (Beirut: Dār al-Madār, 2002), 290.

${ }^{4}$ Elsye Semerdjan, "Naked Anxiety: Bathhouses, Nudity, and Dhimmi Woman in 18th Century Aleppo," International Journal of Middle East Studies, no. 45 (2013): 657.

5James Grehan, "Smoking and 'Early Modern' Sociability: The Great Tobacco Debate in the Ottoman Middle East," The American Historical Review 111, no. 5 (2006): 1375. 
to the Ottoman people. They were not likely to pray, fast, and to perform pilgrimage to Mecca either. Even further, there was a tendency, from certain Sufi orders, to believe in the inconsequential of the Day of Judgment, hence they emphasized rather to the mundane life of here and now. ${ }^{6}$ Based on these facts, therefore, perhaps it is not too exaggerating for many scholars to suspect the Sufis as the root of the crisis and thereupon direct their condemnations toward the suffis.

The Sufis' unorthodoxy issues have long become a slanderous gossip among the non-Sufi 'Ulamā'. Embarking from the commonly believed opinion in which the Sufis had to hold responsibility for the crisis of morality, a group of concerned 'Ulam $\bar{a}^{\prime}$ - that in the later days were assembled under the name of Kadizadeli — viewed a non-negotiable necessity of religious reform. That was done by calling back people to return to the fundamental source of Islamic teachings, namely, the holy Qur'an and the prophetic traditions, and by erecting the socalled principle of "commanding right and forbidding wrong" (al-amr bi al-ma'rüf and al-naby 'an al-munkar). In the beginning, the campaign was unpopular as the endeavors were restricted only to intra-mosque activities such as Friday sermons, informal religious advices, and study groups. However, by mid of the $17^{\text {th }}$ century, the movement indicated a drastic transformation. It metamorphosed from mere intra-mosque campaigns to conspicuously the empire's affairs. This occurred when Kadizade (d. 1635) took over the movement's control and successfully persuaded the Sultan (Murad IV) to agree upon their methods.7 With Sultan's support behind their activities, they successfully motivated many people to execute their mission. Accordingly, Ibn'Arabi's writings were banned, ${ }^{8}$ many

'Thomas McElwan, "Sufism Bridging East and West: The Case of Bektashis," in Sufism in Europe and North America, ed. David Westerlund (New York: Routledge, 2004), 103.

${ }^{7}$ Madeline Zilfi, "The Kadizadelis: Discordant Revivalism in Seventeenth-Century Istanbul," Journal of Near Eastern Studies 45, no. 4 (1986): 275.

${ }^{8}$ Katib Celebi, The Balance of Truth, trans. G.L. Lewis (London: George Allen and Unwin, 1957), 81. 
taverns and coffeehouses were demolished, smokers were inflicted by severe punishment for opposing the official banning of tobacco, etc. ${ }^{9}$

Although gaining Sultan support, Kadizade reform agendas were seemingly dull against the alleged heretic rituals and customs of the Sufis. The reason was because Murad IV did not wholeheartedly declare a war against Sufism since, like many of his forefathers, he also had a very strong connection with certain Sufi orders. ${ }^{10}$ The greater success was accomplished when Muhammad al-Usțuwānī (d. 1661) claimed the movement's leadership in around the year of1655. This happened when the six-years old Mehmet IV (d. 1687) was appointed as a Sultan replacing his father Ibrahim I( d. 1648), the mad Sultan, who was sentenced to death due to a mental problem. Realizing the Sultan's incompetency, Ustuwānī persuasively approached the grand vizier and successfully secured the government's support to embrace their reform plans. Although their anti-Sufi campaign was seemingly successful, the actual implementation of such campaign seemed to hit the wrong target. For example, Usțuwānī urged his sympathetic listeners to attack not only the regular Sufi brethren, but also mere visitors to their lodges. Those who were seized would be given a choice between renewing their faith or death. ${ }^{11}$ Therefore, probably due to this blunder, this wave did not seem to have a long age. When the position of grand vizier was occupied by Köprülü Mehmed (d. 1661), the agenda was forcefully shutdown. Usțuwānī was arrested and had to endure a scorning exile to Cyprus in 1656.

In spite of the fact that Köprülü had successfully put out the distortion, it seemed that he did not sincerely execute his action. This indication was crystal-clear. First, Usțuwānī was never really exiled as he returned again to Damascus, his birthplace, in about one year after the issue of banishment. ${ }^{12}$ Second, and the even

\footnotetext{
9Zilfi, "The Kadizadelis," 257.

${ }^{10}$ Ibid.

${ }^{11}$ Ibid., 258.

${ }^{12}$ James Muhammad Dawud Currie, "Kadizadeli Ottoman scholarship, Muhammad ibn 'Abd al-Wahhāb, and the Rise of the Saudi State," Journal of Islamic Studies 16, no. 3 (2015): 271-2.
} 
clearer evidence, is Korpulu's son, Fazil Ahmad (d. 1676), who succeeded his father's job, co-operatively encouraged the third wave of the Kadizadeli's reform movement led by Vani Mehmed (d.1685). Their coalition managed to secure numbers of influential positions within the Ottoman governmental system. There were no significant differences between the current Kadizadeli's method of campaign and the previous one. In general, it involved anti-Sufi propagandas that in many cases were paired with physical punishment and vandalism. In 1683, Vani was appointed army preacher for Vienna campaign. Unfortunately, due to the Ottoman failure in this war, he was banished to his place of origin near the town of Bursa, and died two years later in $1685 .{ }^{13}$

So far, the socio-political turbulence that appeared as the result of Sufi-Kadizadeli hostility was quite catastrophic. It shed blood, vandalized properties, and destructed reputation. The uncertainty of 'what really happened' during this specific period has forced many scholars to speculate on this issue. Consequently, polemics emerge as the result of the ambiguous speculations. Some took side the Kadizadeli while others defended the Sufis. Both are in the extreme position of bigotry. To the supporters of Kadizadeli, Sufis were bent, they spread religious heresies and cause crisis of morality, hence need to be straightened through all possible means. On the contrary, the blind apologists of the Sufis accused the Kadizadeli of being ignorant and ill-motivated. Hence, this leaves a big question: Did hostility really happen between the two groups? If yes, to what extent did such hostility happen?

\section{Examining Sufism-bid'ab relationship}

The romance between the Ottoman Empire and the Sufis has been tied for a very long time. The oldest traceable record is

${ }^{13}$ Necati Oztturk, "Islamic Orthodoxy Among the Ottomans in the Seventeenth Century with Special Reference to the Qadizade Movement" (Ph.D. Dissertasy, University of Edinburgh, 1981), 276. , 276; and for Ottoman defeat at Vienna see Douglas E. Streusand, Islamic Gumpowder Empires: Ottomans, Safavids, and Mughals (Philadelphia: Westview Press, 2011), 58-60. 
reported by Samer Akkach over the treatise attributed to Ibn'Arabi predicting the rise of the Ottoman dynasty. ${ }^{14}$ Although it has a questionable authenticity status, the impact of such a prediction was undeniably encouraging, let alone it was a foretelling from a highly celebrated Sufi master like Ibn Arabi. Therefore, probably due to this reason, Sufism grew to be a highly demanding trend during Ottoman period.

In the $17^{\text {th }}$ century of Ottoman, people's motive to join Sufi way endured a very serious problem. Technically speaking, the word Tasawnuf (Sufism) is derived from the word Süf (wool). The wool garment is a symbol of piety (Taqwa) since it was the garment of the pious people who lived during, and even before, the time of the Prophet. Therefore, ideally speaking, to be a Sufi means to follow the example of the Prophet and those pious, not only in their appearance, but, more importantly, in the way they lived and served God. On the contrary, in mostly Ottoman cases, one became a member of a certain Sufi order while hiding many concealed motives. It could be popularity since many high-ranking 'Ulama' were Sufis, or additional income from Sufis' businesses such as tobacco and coffee, and even spying considering the long history of enmity that happened between the Shi'ite-Safavid and the Sunni-Ottoman Empire. ${ }^{15}$

The phenomenon of motivation-shift within the institution of Sufism was primarily caused by misconceptions and misconceptualizations of the mystical doctrine and practice by several Sufi orders. In this sense, both the mystical doctrine and practice failed to cover the complete structure of the standard model of Sufism which had long been actualized by the previous mainstream Sufi masters such as Suhrawardī, al-Ṭūsī, al-Ghazālī, etc. Strictly speaking, the $17^{\text {th }}$ century Sufis had gone beyond the boundary of ideal Sufism, hence led to the widespread of religious heresies (bid'ab) and demoralization. This case happened in all over Ottoman land without exception, and even

${ }^{14}$ Samer Akkach, 'Abd al-Gani al-Näbulsi: Islam and the Enlightenment (London: Onew orld Publication, 2007), 15.

15Zeynep Yurekil, Architecture and Hagiography in the Ottoman Empire: The Politics of Bektashi Shrines in the Classical Age (USA: Ashgate Publishing, 2012), 28-9. 
worse in certain region such as Balkan and Amasya. The questions, at this point, are: (1) Were all Sufis of the $17^{\text {th }}$ century Ottoman heretic? (2) Were there any Sufi orders, or at least an individual among them, who still at the straight path?

As a matter of fact, taking a generalization on whether Sufism during $17^{\text {th }}$ century of the Ottoman time was heretic or mainstream, orthodox or unorthodox, was a very risky decision to take. This issue has trapped many scholars in blunder for taking side one group and opposing the other. A thing that should be kept in mind when tackling this case is that the term Tasamwuf (Sufism) during this period has endured extreme deflection. The classic usage of Sufism indicates it as the pure commitment of oneself to dive in the ocean of divinity by means of resembling the Prophet in everything. In the simpler expression, it is the practice of the Shariah at the level of Ihsan. ${ }^{16}$ All the high-esteemed Sufi masters concurred to this definition. ${ }^{17}$ Even a jurist like Abū Ishāqal-Ṣhātibī praised the practitioners of Sufism for their sincerity in worshipping God and their willingness to uphold the Shari $a$ h. $^{18}$ The shifting of meaning of the term tasawnuf had occurred in the later periods when Muslims encountered the cultural heritages of other civilizations such as Persian mysticism and Turk shamanism. The result of such encounter was quite detrimental in a sense that it caused the emergence of a new direction of mysticism that at the same time it was neither completely Islamic nor entirely unislamic. This syncretic Sufi order offered a package of doctrines, rituals, and customs that full of heresies and innovations. The masters of this order were closer to shaman rather than a Shaykh. They 'developed' the already established Suni-mystical doctrine, omitted parts they disliked, adopted and installed in it the culture of their own, and turned it into a new

${ }^{16}$ Syed Muhammad Naquib al-Attas, The Positive Aspects of Tasawnuf: Preliminary Thoughts on An Islamic Pbilosophy of Science (Kuala Lumpur: Islamic Academy of Science, 1981), 1.

${ }^{17} \mathrm{Abu}$ 'Abbās Ạ̣mad ibn Ạ̣mad al-Fāsī, Qawāòid al-Tasannwnf (Beirut: Dār al-kutub al-'Ilmiyyah, 2003), 22.

${ }^{18}$ Majdī Muhammad Muhammad 'Āshūr, Al-Thäbit wa al-Mutaghayyirat fi fiker al-Imām al-Shātịibi (Dubai: Dār al-Buhūth, 2002), 453-62. 
doctrine that is completely loaded with heretic traits. The followers of such orders were very popular with their disentanglement from religious bounds. Therefore, it can be said that Sufism during this period was neither orthodox, since many orders were proved syncretic, nor unorthodox, since the great numbers of them still maintained their primordial Sunni characteristics. For this reason, Halil Inakcik, the author of "Tärīkh al-Dawlah al-Islämiyyah min al-nushū' ilà al-inhidār," proposed two classifications of Sufism within the Ottoman Empire. The first is the well-known Sufi orders of which their tekke was financially supported by the government's endowment foundation as well as the elites of the empire, and that of who had a clear structural organization and a definite brand such as Naqshabandiyyah, Mavlevi (Mawlawiyyah), Halveti (Khalwatiyyab), and Qadiriyyah. The second is the combination between the mystical heritage of the Turks - that was usually known as Malamior Malamitiyyah - and the Islamic mysticism such as the wandering Daräwish known as al-Qalandariyyah, al-Haydariyyah, alAbdāl, and al-Bäba'iyyah; the followers of al-Hamzawiyyahorder; alBayramiyyah, al-Hurüfiyyah, and al-Biktāshiyyah (Bektashi). ${ }^{19}$

The influence of the syncretic Sufism was extremely overwhelming in the period of $17^{\text {th }}-18^{\text {th }}$ century of Ottoman. To tell the truth, when historians talked about Sufism as the highly demanded trend of the people at this specific period they in fact referred to this kind of Sufism rather than to the mainstream one. This claim is not without proof. Halil Înakcik, for instance, found an astonishing fact when investigating the influence of the Bektashi order in Istanbul. His finding revealed that in $19^{\text {th }}$ century one-fifth of the city residents had embraced Bektashism as their mystical way of life, ${ }^{20}$ the number of its lodge (tek.ke) reached seven hundreds spread in all Ottoman cities, ${ }^{21}$ and even the legendary Turk revolutionist, Mustafa Kamal Attaturk, according to some scholars, was rumored to have connection with this order. $^{22}$ Furthermore, Bektashi's well-known

${ }^{19} \bar{I}$ nalcik, Tärikh al-Dawlah, 288-9.

20Ibid., 300.

${ }^{21}$ Ibid.

22McElwan, "Sufism Bridging," 97. 
reputation seemingly was not restricted to the Ottoman domains. Through historical approach, Thomas McElwan has successfully traced back the roots of Bektashism that widely mushroomed in the Europe as well as the America. ${ }^{23}$ In short, the syncretic Sufism has grown to be a very powerful stream for several reasons: first, its fame had exceeded the boundaries of nation and second, it had an extremely great control of the people externally and internally.

The influence of the syncretic Sufis emerged in many areas. In Politics, their dominance led them to secure the utmost position and control at the heart of the Ottoman armed forces, the Janissary. ${ }^{24}$ The impact of this control was very determining and powerful. Their coalition even dared to rebel against the Sultan several times. Finally, in the $17^{\text {th }}$ century, they were able to counterplot Sultan Ibrahim I - who tried to disband the Janissary and replace them with the more controllable corps, removed him from the throne, and put him under capital punishment. ${ }^{25}$ Primarily due to this disloyalty, the corps were then officially shut down by Sultan Mahmud II in 1826. ${ }^{26}$ In economy, the undying activities of the lodge invited the merchants' attraction to do their trading. The followers of syncretic orders also participated constantly in business. Unlike the mainstream Sufis who firmly uphold the practicing of Shariah, the permissiveness of syncretic Sufis allowed them to

23Ibid., 98-101.

${ }^{24}$ Albert Doja, "A Political history of Bektashism in Albania," Totalitarian Movement and Political Religions 7, no. 1 (2006): 84-101.

${ }^{25}$ The rebellion was based on the sultan's attempt to neutralize janissary's influence within Ottoman administration and territories. Unfortunately, the elites of janissary overheard Sultan's plan and counteracted it by plotting dethronement of the Sultan followed by the decree of his execution in the later day. Muhammad Farīd Bek, Tärikh alDawlah al-'Aliyyah al-'Uthmāniyyah (Beirut: Dār al-Nafā'is, 1981), 288.

${ }^{26}$ Edlira Osmani, "God in the Eagles' Country: The Bektashi Order," Quaderns De La Mediterrania, no. 17 (2012): 112. For more details see John Kingsley Birge, The Bektashi Order of Dervish (New York: Midpoint Trade Books Incorporated, 1994), 74-7. Cemal Kafadar, "Janissaries and Other Riffraff of Ottoman Istanbul: Rebels without a Cause," International Journal of Turkish Studies 13, no. 1 \& 2 (2007): 113-34. 
obtain profits even from the prohibited things (Muharram) such as wine (Khamr). With this benefit, they were able to establish and retain their dominance in the market, an achievement that in the later day evoked jealousy from the non-Sufis merchants and thus, according to some scholars, triggered the hostility between the Sufis and the Kadizadelis. In mysticism, the syncretic Sufis were able to severely transmit their heretic 'disease' to the mainstream Sufi orders. For example, the Halveti order was undoubtedly Sunni in nature. However, when the order headquarter moved to the city of Amasya-where many followers of the syncretic Sufi order dwelled, internal conflicts began to heat up and finally resulted in the establishment of the left-wing Halveti. ${ }^{27}$ B.G. Martin asserted, "The Khalwati has experienced a number of oscillations, at one time approaching Shi'ism, at another achieving a stage of nearly an unimpeachable of Sunni orthodoxy." 28

For those who have no knowledge of Islamic mysticism, distinguishing the mainstream Sufism form the syncretic one is never an easy matter. If seen from the outside, both seemed to have no difference at all. Normally, each the mainstream and syncretic Sufi order was composed of the master (Shaykh) to guide and the seeker (Murid) to be guided; both mystical teachings, as well, consisted of theory and practice which often took place in a private lodge; and the two were also bound by the usage of identical technical terms -suchas maqamat (stations) and ahwäl (mystical conditions) - that largely colored their mystical doctrines. Nevertheless, when both are viewed from the inside, it is crystal clear that there were numbers of sharp

${ }^{27}$ Majority residents of Amasya were the Shi'ites. The tight relationship between Shi'ism and the syncretic Sufi orders was never a secret. Some even describe mystical order such as Bektashism as Shi'ite's mask-or even the 'spy' of the Ottoman's rival enemy, the Savavid —within the Sunni Ottoman Empire. Hence, it was never a surprise for Halveti to struggle, and finally to transform, within such intimidating oppression. See Osmani, "God in the Eagles'," 278.

${ }^{28}$ B.G. Martin, "A Short History if the Khalwati Order of Dervishes," in Scholar, Saints, and Sufi, ed. Nikki R. Keddie (London: The Regent of the University of California, 1978), 276. 
differences that fundamentally separated them from one another.

For instance, one of the most noticeable contrasts of the two appears clearly in the doctrinal understanding and application of so-called "Waḅdat al-Wujud" (The unity of Existence). ${ }^{29}$ Generally, the syncretic Sufis believe that there is no difference between the Necessary Being (Wäjib al-Wujūd) and the contingency beings (mumkin al-wujūd). In other words, both are identical thus share equal quality. Frasheri, an Albanian poet who embraced Bektashism, clearly stated "In this world Man is the representative of God ... All things are in man, yea, even the God of Truth." 30 Since there is no gap that separates the domain of God from that of man, they primarily assume to have united with God (ittihad) or that God has incarnated in them (bului), therefore, with this faith in the heart, they claim to be sinless and Sharíab-free. Consequently, religious obligations such as prayer and fasting during the month of Ramadhan were no longer valid for them; there is no boundary of religion as for them all religion is the same, and everything is permissible (halat) since nothing is ethically and legally prohibited if God is in them. ${ }^{31}$ Additionally, it was also this doctrinal error that is mainly responsible for the emergence of colossal misunderstanding toward Ibn'Arabī who was, in many cases, accused as the infidel Shaykh (al-Shaykh al-käfir). In conclusion, the doctrine of Wabdat al-Wujüd has endured drastic transformation in both understanding and application to the extent that resemble pantheism rather than Islamic teaching. ${ }^{32}$

On the other side, the prominent Sufi masters, from the very beginning, have emphasized the absolute differences

${ }^{29}$ This doctrine is pivotal to discuss since most of the syncretic Sufis' heresies were built on its foundation.

${ }^{30}$ Enika Abazi, and Albert Doja, "Further Considerations on the Politics of Religious Discourse: Naim Frasheri and his Pantheism in the Course of Nineteenth-Century Albanian Nationalism," Journal of Middle Eastern Studies 49, no. 6 (2013): 44.

${ }^{31}$ McElwan, "Sufism Bridging," 103.

${ }^{32}$ H.T. Norris, Popular Sufism in Eastern Europe: Sufi Brotherhoods and the Dialogue with Christianity and 'Heterodoxy' (Abingdon, Oxon: Routledge, 2007), 39. 
between God and mankind. ${ }^{33} \mathrm{Al}-\mathrm{Na}$ bulsī strongly asserted "If you heard us saying $W$ aḅdat al-Wujüd, then please be aware...that we are actually differentiated between the unity of Being ( $W$ a h.dat al-Wujūd) and the multiplicity of beings (kathrat al-mawjüd)"34 Similarly, al-Witrī stated "If you heard we say that the existence (al-wujucd) is God, it did not necessarily mean that all existents (mawjüdàt) — whether they are intelligible (ma'qulät) or tangible (mahsussät) - is God. What we really intended to say is that verily the existence that conditions and sustains the existence of all things is God, thus one of his Divine names is the Ever-Living and the Sustainer of all existence (al-Hayy al-Qayyum)"35 From the above statement some principles are inferred. First, Wujüd is one while mawjüd is multiple. Second, $W u j u \bar{d}$ is absolute while the manjüd is conditioned. Third, Wujūd exists on its own while mawjüd has no existence in reality. ${ }^{36}$ Based on this fact, Allah is the only Wujüd in reality (al-Wujüd al-Haqiqi) while other than Him is in the state of absolute non-existence (al-'adam almutlaq). ${ }^{37}$ God, through His Divine Will and Omnipotence,

${ }^{33}$ Although Wabdat al-Wujüdis often claimed to be to be the new mystical doctrine attributed to Ibn'Arabī, its essence actually has long been discussed by the pre-Ibn'Arabi Sufis. It was presented by al-Gazāli in his Ihyā when tackling the classification of tawhìd. See Abū Hāmid Muhammad bin Muḥammad al-Gazālī, Ihyà'’ Ulùm al-Dìn (Cairo: Dār al-Hadīth, 1992), 306-24., 306-324; Al-Gazāli also raised the same issue in his book Mishkeat al-Anwār. However, instead of using the term of Waḅdat al-Wujūd, al-Gazāil preferred the word light $(N \bar{u} r)$ as the symbol that represents the Absolute Oneness of God (Muṭaq al-Ahadiyyah of God) and darkness (Zulmab) to portray the non-existent ('adam) see Abū Hāmid Muhammad bin Muhammad al-Gazāin, Mishkeàt al-Anwār, trans. W.H.T. Gairdner (New Delhi: Kitab Bharavan, 1988), 58.

34'Abd al-Gan̄i al-Nābulsī, Al-Wujūd al-Haqq wa al-Khitāb al-Ṣidq (Damascus: I'Institut Francais d'Etudes Arabes de Demas, 1985), 13.

35Muhammad 'Alī 'Abd al-Zāhīr al-Witrī, Mukhtasar al-Wujūd wa Mir'āt al-Shubüd: Fawā'id Jalïlah Takshifu 'an Ma'nā Wạ̣dat al-Wujüd wa Masāil Qalīlah Tuqarribu Asla mà Dhahaba Abl Trfān wa al-Shubüd (Tokyo University Library: Daiber Collection catalogued as Ms.44 [1207]), 4a.

${ }^{36}$ The True Existence exists by His own and not by thing that is additional to Him. 'Aḍ al-Dīn 'Abd al-Raḥmān al-Ījī, Sharḥ al-Mawāqif, vol. 3 (Beirut: Dār al-Kutub al-'Ilmiyyah, 1998), 5-7.

${ }^{37} \mathrm{Abd}$ al-Ganī al-Nābulsī, Al-Hadīgah al-Nadiyyah Sharb al-Ṭariqah alMuhammadiyyah (Istanbul: Ihlas Vakfi, 1989), 17. 
determines and decrees the existence of everything, so do their life, fate, and etc., and brings them from the state of nothingness to existence which in reality is conditioned by the Divine Existence of God. In summary, the prominent Sufis consider Waḅdat al-Wujud as the translation of tawhidin descending mode. This comprehension is not obtained by formal learning. Rather, it is a gift ('atā) from God to whoever He wants among His servants. $^{38}$ Those servants who never stop seeking for knowledge and truth, actualizing their knowledge into concrete practice, and persistently purifying their inner self (Tazkiyat alNafs) from the 'inconspicuous Shirk' (al-shirk al-khafiy).

The dynamic disaster that was brought by "pseudo Sufism", including the syncretic Sufi orders, is not a new issue within the discourses of Islamic mysticism. For centuries, their heresies have strongly irritated the mainstream scholars, including the most celebrated individual among the Sufi masters. Al-jili for instance, in his Isfär, which is the exposition of Ibn'ArabìsRisälat al-anwàr, wrote a very severe criticism regarding this issue:

"O my brother, May Allah be merciful toward you! I have travelled to the faraway country and associate closely with many kinds of worshipers, thus my eye did not see and my ear did not hear something more evil, viler, and more distant to the side of Allah than the group of people that claims to be the perfection of Sufism. They ascribe themselves to perfection and appear in their image. Nevertheless, they have no faith in Allah, His Messengers, the Doomsday, and have no bond with the obligations of Shariah. They affirm the conditions of the Messengers and the Revelation sent down to them in the unacceptable manner for whosoever bears in his heart an atom's weight of faith, let alone those who already arrived at the level of spiritual unveiling (al$k a s h f)$ and realization (al-iyan). We have seen groups of them. The largest number of them can be found in Azerbaijan, Shirvan, Gilan, and Khurasan. May the wrath of Allah be upon them! Therefore O my brother, do not stay in the country in which one of this groups live, as Allah has warned, "And fear a trial which will not strike those who have wronged among you exclusively, and know that Allah is severe in penalty". How ever, if it is hard for you to realize, at least keep away your sight from them and do not live closely to them, how can you befriend and mingle with them [after the strong warning from Allah].

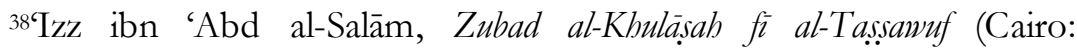
Maktabat al-Thaqāfah al-Dīniyyah, 2009), 88. 
Nonetheless, if you do not do [as $\mathrm{i}$ advise], then there is no point in advising you. Allah is the only Guide. ${ }^{39}$

Furthermore, about two centuries earlier, Ibn'Arabī — who was allegedly charged with the crime of pantheistic Sufism launched fierce critiques to the heresies of his contemporary Sufis. For example, he denounced the practice of remembrance (dhikr) that was often performed with certain movement such as whirling or dancing. For him, remembering God must be executed in absolute humility and submission, this can be accomplished through total motionlessness and silence. He also condemned the Sufis who claimed to have reached the level of incarnation (bulūi) or unity (Ittihad). ${ }^{40}$

In the context of $17^{\text {th }}$ century of the Ottoman, the same tradition, the self-criticism tradition, or the "critics from within" as many prefer to use, was still inherited by many mainstream Sufi masters. Among the most celebrated of them is Ibrāhìm alKurānī in Hijaz and 'Abd al-Ghānī al-Nāblusī in Damascus. For example, Kurānī wrote an extensive explanation of Waḥdat alWujüd for his pupil at the land of Java who asked him about the misapplication of such doctrine at that land. ${ }^{41} \mathrm{He}$ also wrote two other treatises in $W$ ahdat al-Wujüd in which he defended the true tawbidic characteristic of the doctrine while at the same time attacking those fake Sufis for their ignorance and heresies. ${ }^{42} \mathrm{Al}-$ Nābulī also manifested his criticism in the form of writings.

${ }^{39}$ 'Abd al-Karīm ibn Ibrāhīm Al-Ji1̄i, Al-Isfār 'an Risālat al-Anwār fìmā Yatajallā li Abl al-Dhiker min al-Anwār (Beirut: Dār al-Kutub al-'Ilmiyyah, 2004), 45. It is also mentioned by 'Abd al-Razzāq al-Bayțār in his book Hilyat al-bashar when translating Sa'īd al-Khālidī al-Dimashqī. See 'Abd alRazzāq al-Baytāar, Hilyat al-Bashar fì Tärikh al-Qarn al-Thälith al-'Ashar, vol. 2 (Beirut: Dār al- Ṣādir, 1993), 673.

${ }^{40}$ For Ibn'Arabi critics toward Sufism, see Zakī Sālim, Al-Ittijāh al-Naqdì Inda Ibn 'Arabi (Cairo: Al-Maktabah al-Sūfī, 2005), 144-85.

${ }^{41}$ For the influence of the Pseudo Sufis in the land of Java, See 'Abd alRạ̣mān Badawī, Shațahat al-Ṣ̂yfyyyah (Kuwait: Wikālat al-Maṭbūāt, n.d.), 191 9 .

${ }^{42}$ The two treatises are Matla' al-jüd bi tahqiq al-tan₹īh fi $W$ aḅdat al-Wujüd and Jalä' al-nazar fi baqä' al-tan₹̄h ma'a al-tajalli fi al-sunvar see Ibrāhīm alKūrānī, Rasāill fì Waḅdat al-Wujūid (Cairo: Maktabah al-Thaqāfah, 2007), 45155, 83-92. 
Beside a treatise called İdāh al-maqșùd min ma'naWaḥdat al-Wujūd, he has contributed two major books that become the cornerstone of the doctrine's apology. ${ }^{43}$ Moreover, al-Nabūlsì's case is rather interesting to highlight. He was once the student of Muhammad al-Usțuwāni, the most charismatic leader of Kadizadeli. The tight relationship of the two has seemingly escaped the scholars' attention when discussing the hostility that occurred between the Sufis and Kadizadelis. Nabūlsī even composed a poetry when his mentor, al-Usțuwānī, died. ${ }^{44}$ This fact of course has brought a question in mind "was there really hostility between Sufi and Kadizadeli?"

In conclusion, based on the above explanation, at least four points can be inferred. First, Sufis of this period can generally be divided into two main groups, the mainstream-Sunni Sufis and the syncretic Sufis. Second, the mainstream Sufis maintained the upholding of the pure Islamic teaching while the syncretic Sufis combined Islam with the intellectual and cultural heritage of the native. Third, the mainstream Sufis consistently erected the axiom principles of Shari $a b^{45}$ while the syncretic Sufis tended to be heretic and lawbreakers of the Shariah. Fourth, the mainstream Sufi masters persistently fought against the heresies and deviations made by the syncretic or pseudo-Sufis. These points are extremely important to keep in mind since many

43The two books are al-Wujüd al-mutlaqwa al-khitäb al-sidq and al-Fath alRabbāni wa al-fayd al-Raḅmāni. 'Abd al-Ganī al-Nābulsī, Al-Fatḥ al-Rabbānì wa al-Faỵ al-Raḥmānì (Beirut: Dār al-Kutub al-'Ilmiyyah, 1985).; and al-Nābulsī, Al-Wujūd al-Haqq.

44Muhammad Kamāl al-Dīn Al-Gazzī, Al-Wird al-Unsī wa al-Wārid alQudsi fì Tarjamat al-'Árif 'Abd al-Gani al-Näbulsī, ed. Samer Akkach (Leiden: Brill, 2012), 143-4.

${ }^{45}$ Upholdig the shariah is compulsary for every Sufi. In Qawäid altasawnuf (The principles of Sufism) al-Fāsī has enlisted many reasons why a Sufi should embrace the elements of shariah in his daily mystical practice. One of the most famous principal mentioned is the saying of Imām Mālik "He who practices Sufism without learning the Sacred Law corrupts his faith, while he who learns the Sacred Law without practicing Sufism corrupts himself. Only he who combines the two proves true." al-Fāsī, Qawäid al-Tasawwuf, 22. 
scholars are repeatedly fallen into the traps, either to become the blind apologist of the Sufis or the ignorant antagonist of them.

\section{Reconsidering Kadizadeli's anti-Sufi campaign}

An attempt to bring back people to uphold the Shari'a has passed through very long episodes during the Ottoman reign. Many upheavals popped out in all over Ottoman regions demanding for a better religious atmosphere. Figures of powerful influence began transforming their regular sermon into rigorous movement that stirred the mass to eradicate evils from the Ottoman soil. Among the most important figures that must be mentioned in this relation is IbnTaymiyyah (d. 1328), ${ }^{46}$ the most celebrated scholar and the most controversial one whose ideas turned into the most important cornerstone of the later revivalists. Although being criticized by many scholars, IbnTaymiyyah's endeavors to battle the heresies of his time were considerably laudable. First, Ibn Taymiyyah's contemporary Muslim brothers were mostly infected by an acute bigotry illness, hence needed to be awakened. ${ }^{47}$ Second, at the same time the religion of Islam gained a rapid growing of new converts; the shifting of Islamic values that occurred in most cases reached the level of syncretism. Hence, although his method was very much problematic, Ibn Taymiyyah can be considered as the most successful figure that established the principle of Islamic revival. Even in recent time the so-called 'Ibn Taymiyyah effects' can be strongly traced back in certain Islamic groups such as the Wahhabian.

About two centuries after the death of Ibn Taymiyyah, when the local mystics dominated the religious practice of the mass, arose a very distinguished scholar namely Birgili Mehmet Efendi (d. 1573) who embraced Ibn Taymiyyah's principles of reform and revival. Birgili believed that all individuals, no matter he was and the position he had, was responsible for preventing the wrongdoing through all the three methods: hand, tongue, and

${ }^{46}$ Muhammad Abū Zuhrah, Ibn Taymiyyah: Hayātubu wa 'Asrubu, Hayātubu wa Fiqhubu (Cairo: Dār al-Fikr al-'Arab̄̄, 2000), 17-26.

${ }^{47}$ For further reading on the condition of IbnTaymiyyah time see ibid., 105-75. 
heart. ${ }^{48}$ Furthermore, He veritably equated the significance of "commanding right and forbidding wrong" with the importance of Jihad. This means, whoever died for the sake of this responsibility had to enter the ranks of the most excellent of martyr. ${ }^{49}$ Birgili wrote two books as the guideline of revival. The first one is his treatise entitled WasiyyatNama known as Risälah al-Birkiliyyah in which he discussed the true concept of tawhid. aThe second is the Tariqat al-Mubammadiyyah that contained the profound discussions about ethics (akbläq), which greatly influenced the readers of his time. ${ }^{50}$ Although Birgili never openly mentioned the influence of Ibn Taymiyyah in his works, especially the last one, the Taymiyyan's color seemed to be too crystal clear to be denied. With regard to the reason of why Birgili hid the name of Ibn Taymiyyah while using his ideas, it was assumed that Birgili wanted to gain people's enthusiasm and to reach his revival objectives without stimulating their uproar. It was quite understandable since Ibn Taymiyyah's reputation was extremely bad among the grassroots of the Ottoman, due to his harsh attack toward Ibn 'Arabī. ${ }^{51}$

Although Ibn Taymiyyah and Birgili had successfully set up the essential frameworks of revivalism, the real episodes just

${ }^{48}$ This principle is taken and based on Qur'an 3: 104 as well as its interpretation which is summarized in the prophetic tradition, "He who amongst you sees something abominable should modify it with the help of his hand; and if he has not strength enough to do it, then he should do it with his tongue, and if he has not strength enough to do it, (even) then he should (abhor it) from his heart, and that is the least of faith." Muslim ibn al-Hajjāj, Sabỉh Muslim (Riyad: Bayt al-Afkār al-Dawliyyah, 1998), 51.

${ }^{49}$ Michel Cook, Commanding Right and Forbidding Wrong in Islamic Thought (UK: Cambridge University Press, 2004), 325.

${ }^{50}$ Karīm 'Abd al-Majīid, "Uthmāniyyūn wa Salafiyyūn: Harakat Qaḍī Zādih bayn Muhāarabat al-Taṣawwuf wa al-'Awdah ilā "Uhūd al-Salaf," Markaz, al-Namä' lil Bubüth wa al-Diräsät, no. 79 (n.d.): 4.

${ }^{51}$ On criticism toward Ibn Taymiyyah see Muhammad Sa’ìd Ramad̄ān al-Būṭī, Al-Salafizyyah Marhalah Zamaniyyah Mubärakah lā Madhhab al-Islämì (Damascus: Dār al-Fikr, 1998), 158-227., 158-227; as for Ibn Taymiyyah’s conflict with Ibn 'Arabī, it seemed that he had taken back all his accusations. Although such claim did not have strong foundation, personally speaking, it brought more peace in the heart of the reader. 'Abd al-Raḥmān al-Sharqāwī, Ibn Taymiyyah al Faqīh al-Mu'adhdhab (Cairo: Dār al-Shurūq, 1990), 201-10. 
started when Kadizade Mehmed, Muhammad al-Ustuwani, and VaniMehmed were positioned successively as the leaders of the movement in the $16^{\text {th }}-17^{\text {th }}$ century. This is also the reason why the post-Birgivi revivals were more popularly labelled with "Kadizadelis" rather than "Birgilis". ${ }^{52}$ Unlike Birgili who was very cautious in performing his mission, the later leaders seemed to prefer a brute method that in many cases were apparently closer to vandalism rather than polite diplomacy. There are at least two points that differentiated Birgili and the later leaders, especially Kadizade. First Birgili knew his authority. Although he personally believed that the three methods of "commanding right and forbidding wrong" must be applied by every person; as the scholar and mosque preacher, he did not force his principles of renewal to be put into an actual practice by the mass. On the contrary, Kadizade vigorously turned his sermons into a mass movement and even employed violence to reach his objectives. Under his command, the Sufis who were captured by his followers were left to choose either to reaffirm their faith or to be killed. Second, unlike Kadizade, Birgili did not recklessly attack Sufism. He was once a member of Baryami order and highly admired the mainstream Sufi masters. ${ }^{53}$ In his Tariqa alMuhammadiyyah, the guideline book of Kadizade movement, he clearly showed his admiration to the true Sufis. Particularly after explaining the guilty of religious innovation (bid'ab), Birgili devoted a special discussion in which he elaborated Junayd alBaghdādī's responses to such heretic innovation. ${ }^{54}$ In contrast, Kadizade seemed to equalize all Sufi orders as the fountain of heresies. Hence, he unstoppably made the new enemies. The most popular story of his enmity with Sufis was recorded by many scholars in his exchanging accusations with the Halveti Shaykh Sivasi Efendi. ${ }^{55}$ Furthermore, like Birgili who once

${ }^{52}$ For more information of the influence of the Kadizadelis see Simeon Estatiev, "The Qadizadeli movement and the revival of Takfiri in the Ottoman age," in Accusations of Unbelief in Islam, ed. Maribel Fierro Hassan Ansari, and Sabin Schmidtke Camilla Adang (Leiden: Brill, 2015), 225-7.

${ }^{53}$ Celebi, The Balance, 128.

${ }^{54}$ Muhammad ibn Bīr al-Birkilī, Al-Ṭariqah al-Mubammadiyyah wa al-Sirah al-Ahmadiyyah (Damascus: Dār al-Qalam, 2011), 57-63.

${ }^{55}$ Celebi, The Balance, 128. 
tasted the droplets of Sufi's wisdom, Kadizade formerly was also the follower of Sufism. ${ }^{56} \mathrm{He}$ attended the Terjumān lodge under the service of Shaykh' Umar Efendi. However, due to his temperament issue, Kadizade found that the mystical life of Sufism was not suitable for him, therefore he quitted and chose the way of speculation. ${ }^{57}$

The spirit of reform continued to be inherited by many figures after Kadizade, ranging from Damascene scholar Muhammad al-Usțuwāni to the most influential reformist Muhammadibn'Abd al-Wahhāb. ${ }^{58}$ With regard to the Kadizadeli movement, it was very unfortunate that all their revivalism agendas had to end up in failures. Many predictions are made to justify this case. Some are less credible and even sound too apologetic. The most reasonable of all is the thesis that argues that Kadizadeli's movement was not wholly for the sake of eradicating religious heresies and revitalizing the so-called principle of "Commanding right and forbidding wrong." This means that the movement actually concealed another motivation that, to a certain degree, was not even praiseworthy. This opinion was upheld by reliable scholars. Madeline Zilfi, for example, signifies that the Kadizadelis' revivalism was mainly motivated by the very strong influence of personal jealousy of the lower-ranking 'Ulam $\bar{a}$ ' to the higher-ranking one, that was dominated by the Sufis. ${ }^{59}$ In other words, it was the attack on

56It seems that Kadizade and Birgili were not the only revivalist leaders who once had affiliation with Sufi order. Far before them, even Ibn'Taymiyyah-who is very famous for his fierce criticism toward Sufism-was believed to have a tie with Qadariyyah order. See George Makdisi, "Ibn Taymiyyah: A Sufi of the Qadiriya Order," American Journal of Arabic Studies, no. 1 (1974): 118-28.

${ }^{57}$ Celebi, The Balance, 132.

${ }^{58} \mathrm{On}$ Kadizadeli's influence over the later revivalism movement especially the Wahhabi see Currie, "Kadizadeli Ottoman," 279-88. ," 279288; Evstatiev also reported to the same idea in his writing see Estatiev, "The Qadizadeli," 225.

59Zilfi, "The Kadizadelis," 268-9. 
the hierarchy of the Sufis or, as Dina Le Gall preferred to express, it was the anti-elitism movement. ${ }^{60}$ Le Gall said,

"The issue was not simply concern over religious accretionism, but also protest over social standing and professional opportunities...all this was no doubt one reason that the Kadizadelis put Halvetis (and to lesser extent Malvevis, Celvetis, and other Sufis) at the center of their campaign of puritanism and anti-elitism" 61

On the contrary to the previously mentioned theory, Marinos Sariyannis suspects that economic interests were behind Kadizadeli's campaign. As it is already asserted in the previous discussion, the businesses of Sufis dominated the Ottoman market. The highly demanded commodities such as coffee and tobacco were monopolized by Sufis. Entertainment sites such as coffeehouses, and even some taverns, were also run by Sufis. Sariyann iinvestigated this case and found out the overwhelming control of mercantile classes over the revivalism campaign that the Kadizadelis desperately fought for. He asserted that,

"The Kadizadel may have thus provided an ideological platform for the Istanbul merchants in their struggle for a more active role in politics. The merchant seem to have chosen the Kadizadeli ideas in order to promote their interest politically..." 62

"...., the Fatwas that there were indeed people in the late seventeenth century who followed Birgivi's ideas strictly, which renders all the more striking the fact that Ribawas never touched upon by the Kadizadelis preachers." 63

${ }^{60}$ Zilfi noted that between 1621-1685, the Kadizadeli Era, Sufi Shaykhs were favorite choices for the five grandest mosques in the city, of the fortyeight appointments, at least nineteen were of the Halveti order (Khalwatiyyah), and some four other of the forty-eight were from Celveti order (Bayramiyyah). See ibid., 267-8. Estatiev, "The Qadizadeli," 224.

${ }^{61}$ Dina Le Gall, "Kadizadelis, Naqsabandis, and intra Sufi Diatribe in Seventeenth-century Istanbul," The Turkish Studies Association Journal 28, no. 1 (2004): 2.

${ }^{62}$ Marinos Sariyannis, "The Kadizadeli Movement as a Social and Political Phenomenon: The Rise of Mercantile Etic?", in Political Initiatives From the Bottom Up' in the Ottoman Empire, ed. Antonis Anastasopoulos, Halcyon Days in Crete VII, A Symposium Held in Rethymno 9-11 January 2009, Rethymno: Crete University Press, 2012, 283.

${ }^{63}$ Marinos, "The Kadizadeli movement as a social and political phenomenon," 285. 
Even Katib Celebi, one of the most notable historians of $17^{\text {th }}$ century Ottoman, a student of Kadizade Mehmed, distrusted the truthfulness of Kadizadelis' revivalism project. He strongly argued that the fierce hostility between Kadizadelis and Sufis was due to personal rivalry in gaining popularity. With regard to Kadizade-Sivasi hostility, Katib Celebi remarked

"For many years this situation continued, with disputation raging between the two parties, and out of the futile quarrelling a mighty hatred and hostility arose between them. The majority of sheykhs took one side or the other, though the intelligent ones kept out of it, saying, 'This is a profitless quarrel, born of fanaticism. We are all members of the community of Muhammad, brothers in faith. We have no warrant from Sivasi, no diploma from Qadizade. They are simply a couple of reverend shaykhs who have won fame by opposing one another; their fame has even reached the ear of the Sultan." 64

In short, Kadizalis's conflict with Sufis was not all about heresies. The problem is too blurred therefore is not judicable issue. However, based on the above explanation, at least it can be temporarily concluded that, like the Sufis that divided into the true and the pseudo category, the Kadizadelis were also made of two types. The first one was the true revivalists who sincerely fought against heresies and did not restrict their agendas only to the Sufis. The second one was the pseudo revivalists who were driven by non-religious motives such as personal interests, political advantages, and businesses and market monopolization.

Apart from the motive problem, another reason that made Kadizadeli vulnerable to criticism is the method they used in executing their revivalism agenda. In this sense, they tended to belittle the standardization of takfir (accusation of unbelief). They made all kinds of heresy equal to unbelief deeds and thus the doers should be punishable by death. ${ }^{65}$ As a result, Kadizadeli's partisans seemed to be extremely cold-blooded. The students of Kadizadelis' 'ulamä' were armed with knives and

${ }^{64}$ Celebi, The Balance, 133.

${ }^{65}$ For further reading of the development of takfirmovement and its relation to Kadizadeli, see Simeon, 214-238. 
cudgel to fight against Sufis; ${ }^{66}$ individual Sufi masters were denounced and beaten; ${ }^{67}$ facilities that belonged to Sufis were vandalized ${ }^{68}$ and the captured Sufis were forced to choose either to reaffirm their faith or to be killed. ${ }^{69}$ Moreover, Kadizadeli's preachers even urged their followers not only to purify themselves, but also, more importantly, to seek for the sinners and forced them, through all possible means to return back to the straight path. No doubt, erecting the truth through violence and vigilante was completely against the principle of justice in Islam. ${ }^{70}$ Therefore, by allowing their unqualified followers to use force in commanding right and forbidding wrong, the elites of Kadizadeli had judgmentally and judicially blundered. Strictly speaking, by doing so, they had stained the noble agenda of Islamic revivalism by false and harmful methods which were not really Islamic in nature.

One of the most astonishing facts in the issue of the SufisKadizadelis conflict is the tight relationship between al-Nāblusī

${ }^{6}$ Marinos, 272.

${ }^{67 Z i l f i, ~ " T h e ~ K a d i z a d e l i s, " ~} 256$.

68Ibid., 256-7. Marinos, 272.

69Ibid., 258.

${ }^{70}$ Birgili's interpretation to the prophet's command "He who amongst you sees something abominable should modify it with the help of his hand; and if he has not strength enough to do it, then he should do it with his tongue, and if he has not strength enough to do it, (even) then he should (abhor it) from his heart, and that is the least of faith" is quite liberal. Birgili insists that all individuals, no matter he is and the position he has, are responsible to prevent the wrongdoing through all methods mentioned in the Prophet command. This idea was criticized by al-Nābulsī. He believes in divisions of duty. In his perspective, there is very striking difference between the duty of "commanding right and forbidding wrong" and the obligation of "enforcing right conduct onto people" (hisbab). The first is allpeople responsibility that has no binding force. However, this duty is restricted only in conveying the 'words' of forbidding the wrong and commanding the right, hence it does not matter whether the addressees accept the call or not. The second is the particular responsibility of the people in authority like Father to his offspring, leaders to his community, and government to their people. The concept of Hisbah in constitutional level must be run by the government through a special institution called wilayat al-hisbah. This department is very important to keep the balance of society. Cook, Commanding Right, 326-7. 
and his mentor, Muḥamamd al-Usțuwānī. ${ }^{71}$ This phenomenon indeed is a thought-provoking case that invites skepticism toward the popular belief on the subject. Scholars hence begin questioning "How can the fundamentalist scholar and the most influential leader of the anti-Sufi movement like al-Usțwāni accepted a Sufi and the most celebrated champion of $W$ abdat alWujüd like al-Nābulsī as his pupil?" To provide an answer for such a question, the writer in the beginning of this paper has tried to employ Steve Temari's categorization of the Ottoman 'Ulama' in which Sufi scholars were divided into two: (1) the followers of al-Shaykhal-akbar Ibn'Arabī (the Akbarian) and (2) the regular Sufis. In this sense, the writer previously believed that the Kadizadeli's attack was actually directed to the common followers of the Sufi path and thus not against the Sufis who gathered under the banner of Akbarian. ${ }^{72}$ Nevertheless, such argument was theoretically weak. The banning of Ibn 'Arabī's writings is more than sufficient evidence to refute such hypothesis. Hence, it was not worthy of consideration.

The writer then looked on Samer Akkach's comment on the issue. Akkach was another scholar who speculated on this paradox. Nevertheless, his opinion seemed to lack credibility.

Unlike Temari, Akkach was rather skeptical in discussing this matter. He doubted the real connection between alUsțuwānī and al-Nāblusī. Commenting on al-Nābulsīss biography al-Wird al-Unsī, Akkach enlisted names of Nābulsìss

${ }^{71} \mathrm{Al}-\mathrm{Gazz} \overline{1}$, Al-Wird al-Unsī, 143-4.

${ }^{72}$ Steve Temari argues that sufism of this time can be divided generally into two groups: the Akbarians and the followers of Sufi path. The former is the champions of Shaykh al-Akbar Ibn'Arabì whereas the latter is the common followers of certain Sufi order. The followers of the Sufi path did not necessarily possess a profound understanding of religious teachings. As a matter of fact, most of them are blind i (Muqallid) and ignorant imitators, who in many cases, held dishonest purpose such as seeking for fame, selfbenefit, and even business profit. On the contrary, The Akbarians mostly are encyclopedic scholars who are expert in many disciplines of knowledge. See Steve Tamari, "The 'Alim as Public Intellectual: 'Abd al-Ganī al-Nābulsī as a Scholar-activist," in Intellectuals and Civil Society in the Middle East: Liberalism, Modernity and Political Discourse, ed. Mohammed A. Bamyeh (London: I.B. Tauris, 2012). 
most influential teachers who were somehow doubtful due to three main reasons. First, al-Ghazzī, the writer of the biography, included someone who al-Nābulsīhad not met, 'Ali alShibrāmils̄ì (d. 1676). Second, al-Ghazzī’s list embraced the antiSufi fundamentalist, al-Usțuwānī (d. 1661). Third, of all the names -of al-Nābulsî̀s formal teachers-that were enlisted by al-Ghazzī, none of them was a Sufi master. Finally, his conclusion states that "al-Ghazzî̀'seems to be interested more in establishing connections with celebrities than in detecting the truly influential figures in 'Abdal-Ganì's life and thought."73

Nevertheless, Akkach's proposition is also dull. In the first argument, he questions the credibility of al-Ghazzî̀s information in which he included the scholar al-Nābulsī he never met. Akkach's assumption is, in fact, based on his misunderstanding on the concept of 'written certification' (al-ijäzah bi alMukātabah). Al-Ghazzī did indeed mention that al-Nābulsī obtained a written certification from the Egyptian Shaykh alShibrāmilsī. With regard to this case, it must be clarified that: first, having certification through writing does not necessarily mean the impossibility of meeting between the certifier (Mujiz) and the certified one (Mustajiz). ${ }^{74}$ Second, the written certification (al-Mukātabah) is one of the agreeable methods of transmission (sanad) in Islamic tradition. ${ }^{75}$ Therefore, refutation of the credibility of this type of transmission is considered a big blunder for a scholar. As for his second argument, the long history of Islamic intellectual tradition showed that many

${ }^{73}$ Samer Akkach, Letter of Sufi Scholar: The Correspondence of 'Abd al-Gani alNäbulsì (Leiden: Brill, 2010), 5.

${ }^{74}$ The discussion on this matter is unquestionably vast. Therefore for further reading please refer to Ibn Kathïr, Al-Baith al-Hathith fi Sharh Ikhtisar Ulüm al-Hadith, vol. 1 (Riyad: Maktabat al-Ma'ārif, 1996), 361-2., 361-2; Ibn 'Amrū Uthmān 'Abd al-Raḥmān al-Sharazurī, Ulūm al-Hadìth lì Ibn al-Ṣalāh (Beirut: Dār al-Fikr, 1986), 173-4., 173-4; Ibn Hajar Al-'Asqalānī, Fatḥ alBārì, vol. 1 (Beirut: Dār al-Ma'tifah, n.d.), 164-9.

${ }^{75}$ Written certification has two categories: the written certification that obviously asserted the word "I certify..." and the written certification that does not mentioned it explicitly. The first type is unanimously agreeable among Muslim scholar whereas the second is not. See Al-'Asqalānī, Fatḥ alBārī, 164-9. 
fundamentalists were not against Sufism. Take for example Ibn Taymiyyah. Although he is often connected with the anti-Sufi movement, he was actually affiliated under the cloak of Qadariyyah. ${ }^{76}$ Another example is the Nusantara Sufi scholar Muhammad Arshad al-Banjārī who took a certification from Murtạ̣ā al-Zabidī on Muhammad ibn 'Abd al-Wahhāb's Kitāb Tawhid. ${ }^{77}$ With regard to the third, it seems that Akkach is too hasty in tackling his research thus it lacks accuracy. Anyone who observes this biography will easily find the Sufi master on the long list of al-Nābulsì's formal teachers such as Muhammad ibn Barakāt al-Kūfì (d. 1665). Additonaly, al-Ghazzī also mentioned other name who was actually a Sufi, for example, Shaykh Mạ̣mūd al-Kurdī who affiliated to Halveti order.

For those who have profound understanding regarding the 'nature of revivalism' in Islam, the so-called "harmony" between the two conflicting sides namely Kadizadeli and Sufi is never a paradox. They are completely aware that among the biggest names in the history of revivalists, if not the majority of them, were the Sufis. Take for example al-Gazālī, 'Abd al-Qādir alJazā'irī, the Nusantara 'Ulāmā' like Yūsuf al-Maqassārī, 'Abd alṢamad al-Fālimbānī, Dāwūd al-Faț̣ānī, and many others. For the orthodox Sufis, combining the Shariah and the Haqiqah is nonnegotiable commitment. Correspondingly, it is unquestionably impossible for them either to practice or to spread the religious heresies to other Muslims. Moreover, similar to Kadizadeli's revivalists who supposedly endeavored against the heretic popular beliefs and customs, the orthodox Sufis were also irritated by such heresies. ${ }^{78}$ Hence, perhaps it was already natural for a mainstream Sufi scholar to criticize and even condemn

76Makdisi, "Ibn Taymiyyah," 118-29.

${ }^{77}$ Wan Muhammad Shaghir Abdullah, Shaykh Mubammad Arsyad alBanjari Pengarang Sabilal Mubtadin (Kuala Lumpur: Khazanah Fathanaiyah, 1990), 24.

${ }^{78}$ The so-called "critic from within" upon the pseudo Sufis' heresy was upheld by the mainstream Sufis since long time ago. In the context of $17^{\text {th }}$ century of Ottoman, arouse many figures such as al-Nābulsi, the Naqshabandi shaykh Ahmad Bosnavi (d. 1664), Nūr al-Dīn al-Ranirī (1658), Burhān al-Dīn Rāzī Ilāhī (d. 1673), and many others. For further reading on this issue, see Gall, "Kadizadelis," 1-15. 
such heresies. Commenting on some of the rituals performed by Sufis, who represented the mystical tradition within Islam, alNabulsi was unable to hide his distaste for the most uninhibited worshippers, who blabbed incomprehensibly and emitted cries which "resembled the braying of a donkey." 79

Not only actively erecting the backbone of Islamic teachings, were the orthodox Sufis also constantly participating in maintaining sovereignty and integrity of the Islamic empires as well. For example, during the crusade Shaykh Arslan obliged his pupils to take part in the military training and to keep the city of Damascus away from the enemies' aggression. It was completely the opposite of the syncretic Sufis, who cares about nothing but themselves. Even worst, in the certain cases, particularly due to their close affinity to Shi'ism, the syncretic Sufis obviously turned into an effective intelligence that collected information of Ottoman for the Savavid Empire from within.

\section{Conclusion}

The Ottoman Empire in $17^{\text {th }}$ century has suffered from many diseases, such as the changing trade route of European market due to the Ottoman's monopolization — which resulted in state revenue decline; ${ }^{80}$ military expansions and high expenditures of wars as well as defeats and losses of large scale territories; ${ }^{81}$ Ottoman's bad economic strategies reflected in devaluation, confiscation, and increasing taxes, ${ }^{82}$ improper educational policies manifested in "Institutionalization of

${ }^{79}$ James Grehan, "The Mysterious Power of Words: Language, law, and Cultures in Ottoman Damascus: 17th -18th Centuries," Journal of Social History 37, no. 4 (2004): 994-6.: 994-6.

80Ross Burns, Damascuss: A History (London and New York: Routledge, 2005), 237-9.

81Donald Quateart, The Ottoman Empire, 1700-1922 (UK: Cambridge University Press, 2000), 38.

82Dick Douwes, The Ottomans in Syria: A History of Justice and Oppression (New York: I.B. Tauris Publisher, 2000), 152-62.,152-162; Omer Lutfi Barkan, "The Price of Revolution of the Sixteenth Century: A Turning Point in the Economic History of the Near East," International Journal of Middle East Study 6, no. 1 Jan (1975): 3-27. 
schools" and "Professionalization of Ulama" $\bar{a}$ "; corrupt and incompetence elites as well as the application of so-called "favoritism" in the employee-recruitment system. ${ }^{84}$ All these problems, as they were commonly believed, were due to the crisis of morality that had infected all stratums of the Ottoman people. Such crisis happened because of the widespread of religious heresies that allegedly promoted by Sufis. To a certain degree, that allegation is not completely wrong, but, at the same time, needs further explanation.

The Sufi of this specific period was generally divided into two categories: the mainstream Sufis and the syncretic or pseudo-Sufis. The first was the true Sufis who upheld the primordial teaching of Islam while the second was the 'cocktail' Sufi who combined Islamic mystical teachings with the local heritage and culture. Based on this fact, when scholars talked about the "heretic of Sufis", this was actually valid for the syncretic type of Sufis and therefore not for the mainstream one. Additionally, the mainstream Sufis had long struggled against the heretic of the pseudo-Sufis. Therefore, many names of Sufis were listed among the most celebrated revivalists in the history of Islamic civilization.

On the other hand, Kadizadeli appeared to be the "hero" that opposed the heresies of Sufis and campaigned for Islamic revival. Nevertheless, many scholars doubted their true intention. Some believed that their campaign was indeed stirred up by jealousy toward the Sufis who, for years, secured the position of the higher ranking 'Ulama'. Other smelled a strong influence of mercantile elites who tried to establish control over the market which was dominated by the Sufis. Although, all of their skeptical opinions were valid, it still did not deny the possible existence of true revivalist among the Kadizadel is such as al-Ustuwānī. Hence, the Kadizadeli case is exactly the same as

${ }^{83}$ Steve Tamari, "Between Golden Age and Renaissance: Islamic Higher Education in the Eighteenth Century Damascus," in Trajectories of Education in the Arab World: Legacies and Challenge, ed. Osman Abi-Marshed (London and New York: Routledge, 2010), 36-58.

${ }^{84}$ Daniel Goffman, The Ottoman Empire and Early Modern Europe (UK: Cambridge University Press, 2004), 112-3. . 
the Sufis. In this sense, Kadizadeli can also be grouped into two: the true revivalist and the pseudo one.

Did Kadizadeli fight against the Sufi? The answer is, as for the pseudo of them, "yes"; they did quarrel with the Sufi and as for the true revivalist of them "no". Why? Because not all Sufi were heretic, the mainstream of them shared the same attempt of eradicating heresies. Take for example Ahmad Bosnavi (d. 1664), Nūr al-Dīn al-Ranirī (1658), Burhān al-DīnRāzịllāhī (d. 1673), al-Nābulsī (d. 1731), Ibrāhīm al-Kurānī (d.1690) etc., who persistently called people to embrace the true teaching of Islam. Hence, unlike many scholars had believed, the harmony between Kadizadeli and Sufi, based on this analysis, is not a paradox and therefore an actual occurrence. The brightest example of this case was portrayed in the tight relationship that bond between the mentor, Muhammad al-Usțuwānī, the most celebrated leader of the Kadizadelis, and the pupil,'Abd al-Ganī al-Nābulsī, the most prominent Sufi masters of his time. If the true Kadizadeli was not against Sufi then what was the object of their revival activities? The answer is obvious; it is bid'ab (religious heresies) in general sense. There is no disagreement among 'Ulamä', of the classical age and even of this contemporary time, on the dangerous potentiality of bid'ah in all aspects of human life. Therefore, both the mainstream Sufis and the true revivalists of Kadizadeli saw revival activities as a 'fixed-price'. They believed $b^{\prime} d^{\prime} a h$, in what form ever it appeared, regardless whoever practiced it or promoted it, whether he was a Sufi or even an the elites of the palace, must be exterminated without exception. The only difference is in the method employed by the two sides in order to realize such agenda. Hence, on the basis of this study, the thing that must be echoed in this case is not "Kadizadeli versus Sufi", rather it is "The true Muslim Scholars versus bid'ah."

\section{References}

'Āshūr, Majdī Muhammad Muhammad. Al-Thābit wa alMutaghayyirat fi fiker al-Imām al-Shätibì. Dubai: Dār alBuhūth, 2002. 
Abazi, Enika, and Albert Doja. "Further Considerations on the Politics of Religious Discourse: Naim Frasheri and his Pantheism in the Course of Nineteenth-Century Albanian Nationalism." Journal of Middle Eastern Studies 49, no. 6 (2013).

Abdullah, Wan Muhammad Shaghir. Shaykh Muhammad Arsyad al-Banjari Pengarang Sabilal Mubtadin. Kuala Lumpur: Khazanah Fathanaiyah, 1990.

Akkach, Samer. 'Abd al-Gani al-Näbulsì: Islam and the Enlightenment. London: Oneworld Publication, 2007.

------. Letter of Sufi Scholar: The Correspondence of 'Abd al-Gani alNābulsì. Leiden: Brill, 2010.

Al-'Asqalānī, Ibn Hajar. Fatḥ al-Bārì. Vol. 1. Beirut: Dār alMa'tifah, n.d.

al-Attas, Syed Muhammad Naquib. The Positive Aspects of Tasawnuf: Preliminary Thoughts on An Islamic Philosophy of Science. Kuala Lumpur: Islamic Academy of Science, 1981.

al-Baytāā, 'Abd al-Razzāq. Hilyat al-Bashar fì Tārikeh al-Qarn al-

Thälith al-'Ashar. Vol. 2. Beirut: Dār al- Șādir, 1993.

al-Birkilī, Muhammad ibn Bīr. Al-Ṭariqah al-Muhammadiyyah wa al-Sirah al-Aḥmadiyyah. Damascus: Dār al-Qalam, 2011. al-Būṭī, Muhammad Sa’̄̄d Ramaḍān. Al-Salafiyyah Marḅalah Zamaniyyah Mubārakah lā Madhhab al-Islämì. Damascus: Dār al-Fikr, 1998.

al-Fāsī, Abū 'Abbās Aḥmad ibn Aḥmad. Qawāid al-Tasannuf. Beirut: Dār al-kutub al-'Ilmiyyah, 2003.

al-Gazālī, Abū Hāāmid Muḥammad bin Muḥammad. Mishkeāt alAnwār. Translated by W.H.T. Gairdner. New Delhi: Kitab Bharavan, 1988.

------. Ibyā' 'Ulūm al-Dìn. Cairo: Dār al-Hadīth, 1992.

Al-Gazzī, Muhammad Kamāl al-Dīn. Al-Wird al-Unsī wa al-Wārid al-Qudsì fì Tarjamat al-'Árif 'Abd al-Ganì al-Näbulsì. Edited by Samer Akkach. Leiden: Brill, 2012.

al-Hajjāj, Muslim ibn. Sạı̄ḥ Muslim. Riyad: Bayt al-Afkār alDawliyyah, 1998.

al-Ījī', 'Aḍ al-Dīn 'Abd al-Rạ̣mān. Sharḥ al-Mawāqif. Vol. 3. Beirut: Dār al-Kutub al-'Ilmiyyah, 1998. 
Al-Jìlī, 'Abd al-Karīm ibn Ibrāhīm. Al-Isfär 'an Risälat al-Anwār fimà Yatajallā li Abl al-Dhiker min al-Anwār. Beirut: Dār alKutub al-'Ilmiyyah, 2004.

al-Kūrānī, Ibrāhīm. Rasāil fì Wạ̣dat al-Wujūd. Cairo: Maktabah al-Thaqāfah, 2007.

al-Majīd, Karīm 'Abd. "'Uthmāniyyūn wa Salafiyyūn: Harakat Qậ̣ Zādih bayn Muhārabat al-Tașawwuf wa al-'Awdah ilā 'Uhūd al-Salaf." Markaz al-Namà' lil Buhüth wa alDirāsāt, no. 79 (n.d.): 1-16.

al-Nābulsī, 'Abd al-Ganī. Al-Fatḥ al-Rabbānì wa al-Fayd alRaḥmānì. Beirut: Dār al-Kutub al-'Ilmiyyah, 1985.

------. Al-Wujūd al-Haqq wa al-Khitäb al-Ṣidq. Damascus: I'Institut Francais d'Etudes Arabes de Demas, 1985.

-----. Al-Hadiqah al-Nadiyyah Sharh al-Tariqah al-Muhammadiyyah. Istanbul: Ihlas Vakfi, 1989.

al-Salām, 'Izz ibn 'Abd. Zubad al-Khulāsah fì al-Tașsanuf. Cairo:

Maktabat al-Thaqāfah al-Dīniyyah, 2009.

al-Sharazurī, Ibn 'Amrū Uthmān 'Abd al-Raḥmān. 'Ulūm al-

Hadith lì Ibn al-Saläh. Beirut: Dār al-Fikr, 1986.

al-Sharqāwī, 'Abd al-Raḥmān. Ibn Taymiyyah al Faqīh alMu'adhdhab. Cairo: Dār al-Shurūq, 1990.

al-Witrī, Muhammad 'Alī 'Abd al-Zāhīr. Mukhtasar al-Wujūd wa Mir'ät al-Shubüd: Fawā'id Jalīlah Takshifu 'an Ma'nā Waḅdat al-Wujūd wa Masāill Qalīlah Tuqarribu Asla mà Dhahaba Abl 'Irfän wa al-Shubüd. Tokyo University Library: Daiber Collection catalogued as Ms.44 [1207].

Badawī, 'Abd al-Raḥmān. Shatahat al-Süfiyyah. Kuwait: Wikālat alMațbū'āt, n.d.

Barkan, Omer Lutfi. "The Price of Revolution of the Sixteenth Century: A Turning Point in the Economic History of the Near East." International Journal of Middle East Study 6, no. 1 Jan (1975): 3-27.

Bek, Muhammad Farīd. Tärikh al-Dawlah al-'Aliyyah al'Uthmāniyyah. Beirut: Dār al-Nafā'is, 1981.

Birge, John Kingsley. The Bektashi Order of Dervish. New York: Midpoint Trade Books Incorporated, 1994.

Burns, Ross. Damascuss: A History. London and New York: Routledge, 2005. 
Celebi, Katib. The Balance of Truth. Translated by G.L. Lewis. London: George Allen and Unwin, 1957.

Cook, Michel. Commanding Right and Forbidding Wrong in Islamic Thought. UK: Cambridge University Press, 2004.

Currie, James Muhammad Dawud. "Kadizadeli Ottoman scholarship, Muhammad ibn 'Abd al-Wahhāb, and the Rise of the Saudi State." Journal of Islamic Studies 16, no. 3 (2015): 271-88.

Doja, Albert. "A Political history of Bektashism in Albania."

Totalitarian Movement and Political Religions 7, no. 1 (2006): 84-101.

Douwes, Dick. The Ottomans in Syria: A History of Justice and Oppression. New York: I.B. Tauris Publisher, 2000.

Estatiev, Simeon. "The Qadizadeli movement and the revival of Takfiri in the Ottoman age." In Accusations of Unbelief in Islam, edited by Maribel Fierro Hassan Ansari, and Sabin Schmidtke Camilla Adang, 225-7. Leiden: Brill, 2015.

Gall, Dina Le. "Kadizadelis, Naqsabandis, and intra Sufi Diatribe in Seventeenth-century Istanbul." The Turkish Studies Association Journal 28, no. 1 (2004): 1-16.

Goffman, Daniel. The Ottoman Empire and Early Modern Europe.

UK: Cambridge University Press, 2004.

Grehan, James. "The Mysterious Power of Words: Language, law, and Cultures in Ottoman Damascus: 17th -18th Centuries." Journal of Social History 37, no. 4 (2004): 994-6.

------. "Smoking and 'Early Modern' Sociability: The Great Tobacco Debate in the Ottoman Middle East." The American Historical Review 111, no. 5 (2006): 1375.

Inalcik, Halil. Tärikh al-Dawlah al-Uthmāniyyah min al-Nushū' ilā alInhidàr. Translated by Muhammad M. al-Arna'ūt. Beirut: Dār al-Madār, 2002.

Kafadar, Cemal. "Janissaries and Other Riffraff of Ottoman Istanbul: Rebels without a Cause." International Journal of Turkish Studies 13, no. 1 \& 2 (2007): 113-34.

Kathīr, Ibn. Al-Bäith al-Hathith fï Sharh Ikhtisar 'Ulüm al-Hadith. Vol. 1. Riyad: Maktabat al-Ma'ārif, 1996. 
Makdisi, George. "Ibn Taymiyyah: A Sufi of the Qadiriya Order." American Journal of Arabic Studies, no. 1 (1974): 118-29.

Martin, B.G. "A Short History if the Khalwati Order of Dervishes." In Scholar, Saints, and Sufi, edited by Nikki R. Keddie, 276. London: The Regent of the University of California, 1978.

Martin, Richard C. Encyclopedia of Islam and Muslim World. USA: Macmillan and Thomson Learning, 2004.

Matthee, Rudi. "Exotic Substance: The Introduction and Global Spread of Tobacco, Coffee, Cocoa, Tea, and Distilled Liquor, Sixteenth to Eighteenth Centuries." In Drugs and Narcotics in History, edited by Roy Porter, 35. Cambridge: Cambridge University Press, 1995.

McElwan, Thomas. "Sufism Bridging East and West: The Case of Bektashis." In Sufism in Europe and North America, edited by David Westerlund, 103. New York: Routledge, 2004.

Norris, H.T. Popular Sufism in Eastern Europe: Sufi Brotherhoods and the Dialogue with Christianity and 'Heterodoxy'. Abingdon, Oxon: Routledge, 2007.

Osmani, Edlira. "God in the Eagles' Country: The Bektashi Order." Quaderns De La Mediterrania, no. 17 (2012): 112278.

Oztturk, Necati. "Islamic Orthodoxy Among the Ottomans in the Seventeenth Century with Special Reference to the Qadizade Movement." Ph.D. Dissertasy, University of Edinburgh, 1981.

Quateart, Donald. The Ottoman Empire, 1700-1922. UK: Cambridge University Press, 2000.

Sālim, Zakī. Al-Ittijāh al-Naqdì 'Inda Ibn 'Arabì. Cairo: AlMaktabah al-Sūfi, 2005.

Semerdjan, Elsye. "Naked Anxiety: Bathhouses, Nudity, and Dhimmi Woman in 18th Century Aleppo." International Journal of Middle East Studies, no. 45 (2013): 657.

Streusand, Douglas E. Islamic Gunpowder Empires: Ottomans, Safavids, and Mughals. Philadelphia: Westview Press, 2011. 
Tamari, Steve. "Between Golden Age and Renaissance: Islamic Higher Education in the Eighteenth Century Damascus." In Trajectories of Education in the Arab World: Legacies and Challenge, edited by Osman Abi-Marshed, 36-58. London and New York: Routledge, 2010.

------. "The 'Alim as Public Intellectual: 'Abd al-Ganī al-Nābulsī as a Scholar-activist." In Intellectuals and Civil Society in the Middle East: Liberalism, Modernity and Political Discourse, edited by Mohammed A. Bamyeh, 100. London: I.B. Tauris, 2012.

Yurekil, Zeynep. Architecture and Hagiography in the Ottoman Empire: The Politics of Bektashi Shrines in the Classical Age. USA: Ashgate Publishing, 2012.

Zilfi, Madeline. "The Kadizadelis: Discordant Revivalism in Seventeenth-Century Istanbul." Journal of Near Eastern Studies 45, no. 4 (1986): 257-70.

Zuhrah, Muhammad Abū. Ibn Taymiyyah: Hayātubu wa 'Asrubu, Hayātubu wa Fiqhubu. Cairo: Dār al-Fikr al-'Arabī, 2000. 